Mathematical Programming 10 (1976) 137.

North-Holland Publishing Company

\title{
NOTICE \\ COUNCIL OF THE MATHEMATICAL PROGRAMMING SOCIETY
}

Following the postal ballot for the election of Treasurer and members of the Council of the Mathematical Programming Society, the Council for the year commencing August 1975-1976 consists of
Professor E.M.L. Beale
(Chairman)
Professor A.W. Tucker
(Chairman-Elect)
Professor F.A. Lootsma
(Treasurer)
Professor J. Abadie
Professor R. Fletcher
Professor D.R. Fulkerson
Professor R.T. Rockafellar
Ex officio
Professor M.L. Balinski
(Editor-in-Chief)
Professor R.W. Cottle
(Chairman of the Executive Committee)

The Chairman of the Program Committee for the Ninth International Symposium - Budapest is Professor Andras Prekopa. 